\title{
POLITIK HUKUM DALAM PEMBAHARUAN PERATURAN \\ EKSTRADISI DI INDONESIA DIHUBUNGKAN DENGAN UNITED \\ NATIONS MODEL TREATY ON EXTRADITION OF 1990
}

\author{
Zarisnov Arafat \\ Muhammad Gary Gagarin Akbar
}

Universitas Buana Perjuangan Karawang

Email: zarisnov@ubpkarawang.ac.id gary.akbar@ubpkarawang.ac.id

\begin{abstract}
Abstrak
Ekstradisi secara universal hingga saat ini mengalami perubahan yang semakin baik, terutama setelah kehidupan bernegara sudah mulai tampak lebih maju sampai abad $20 \mathrm{ini}$. Hubungan dan pergaulan internasional menemukan bentuk dan substansinya yang baru dan berbeda dengan zaman sebelum Perjanjian Perdamaian Westphalia tahun 1648. Negara-negara yang berdasarkan atas prinsip kemerdekaan kedaulatan dan kedudukan sederajat mulai menata dirinya masing-masing terutama masalah domestik dengan membentuk dan mengembangkan hukum nasionalnya, yang salah satunya di bidang hukum pidana nasional. Hukum pidana nasional masing-masing negara, terutama jenis-jenis kejahatan atau tindak pidananya, disamping pula ada kesamaan dan perbedaannya. Semakin menguat batas wilayah dan kedaulatan teritorial masing-masing negara, semakin menguat pula penerapan hukum nasionalnya di dalam batas wilayah negara masing-masing. Semakin banyaknya perjanjian-perjanjian yang dibuat oleh negara-negara baik bilateral ataupun multilateral untuk mengatur suatu masalah tertentu yang sudah, sedang, dan akan dihadapi. Dalam pembuatan perjanjian tersebut mulai dilakukan pengkhususan atas substansinya, jadi tidak lagi satu perjanjian mencakup berbagai macam substansi yang berbeda-beda. Di Indonesia peraturan mengenai Ekstradisi dibuat pada tahun 1979, mengingat hingga saat ini belum terjadi perubahan di dalam Undang-Undang Nomor 1 Tahun 1979 padahal PBB telah membuat suatu model pembuatan perjanjian ekstradisi pada tahun 1990, sehingga sudah selayaknya peraturan mengenai ekstradisi di Indonesia harus mengalami pembaharuan ke depan yang lebih baik.
\end{abstract}

Kata Kunci: Ekstradisi, Politik Hukum, Hukum

Pidana.

Abstract
Extradition is universally up to now experiencing increasingly good changes, especially after the
state of life has begun to appear more advanced until the 20th century. International relations and
relationships find new and different forms and substance from the times before the Treaty of Peace of
Westphalia in 1648. Countries that are based on the principle of freedom of sovereignty and equal
position begin to organize themselves, especially domestic problems by forming and developing
national laws, which one of them is in the field of national criminal law. The national criminal law of
each country, especially the types of crime or criminal acts, besides there are similarities and
differences. The stronger regional boundaries and territorial sovereignty of each country, the
stronger the application of national laws within the borders of each country. The increasing number
of agreements made by countries both bilaterally and multilaterally to regulate a particular problem
that has been, is being, and will be faced. In making these agreements, specialization of the
substance began to be carried out, so no more than one agreement covers a variety of different
substances. In Indonesia, the Extradition regulation was made in 1979, considering that until now
there had been no changes in Law Number 1 of 1979 even though the United Nations had made a
model for making an extradition treaty in 1990 , so that proper regulations on extradition in
Indonesia must undergo reform better future.

Keyword: Extradition, Politics of Law, The Criminal Law. 


\section{PENDAHULUAN}

Di masa kemajuan ilmu pengetahuan dan teknologi saat ini yang begitu pesat, khususnya di bidang transportasi, komunikasi dan informasi, memiliki manfaat yang positif yaitu mempermudah aktifitas manusia untuk mencapai tingkat kualitas hidup yang lebih baik, namun di sisi yang lain dapat disalahgunakan untuk hal-hal yang bersifat negatif pula, misalnya mempermudah peluang terjadinya perbuatan-perbuatan yang melanggar hukum atau bertentangan dengan hukum. Meningkatnya kejahatankejahatan yang bersifat lintas batas negara seperti tindak pidana pencucian uang, kejahatan cyber, kejahatan terorisme, kejahatan narkotika, dan tindak pidana korupsi dianggap sebagai dampak langsung dari kemajuan tekhnologi. Tidak hanya itu, dengan kemajuan transportasi, seorang pelaku kejahatan dapat melarikan diri ke negara lain dengan tujuan untuk menghindari tuntutan hukum.

Untuk mewujudkan penegakan hukum pidana di dalam menangani kasus-kasus kejahatan tersebut, maka kerjasama internasional di bidang penegakan hukum pidana mutlak diperlukan. Komitmen masyarakat internasional untuk menanggulangi kejahatan-kejahatan lintas batas negara melalui kerjasama internasional dapat terlihat dari instrumen-instrumen hukum internasional yang lahir, berupa peraturan-peraturan dalam bentuk perjanjian internasional. Konvensi Palermo $2000^{1}$ misalnya, menyebutkan beberapa bentuk kerjasama internasional yang dapat dilakukan oleh masyarakat internasional, yaitu perjanjian ekstradisi, bantuan hukum timbal balik di bidang pidana (mutual legal assistance in criminal matters), dan pemindahan narapidana (transfer of sentenced person). Kerjasama internasional juga diatur dalam Konvensi PBB (Perserikatan BangsaBangsa) melawan korupsi $2003^{2}$ dan secara khusus mengatur tentang pengembalian aset (asset recovery) hasil korupsi. PBB telah mengeluarkan $U N$ Model Treaty on Extradition berdasarkan Resolusi Majelis Umum PBB Nomor 45/116 tanggal 14 Desember 1990, yang dapat dijadikan

\footnotetext{
${ }^{1}$ Konvensi ini adalah UNTOC (United Nations Convention Against Transnational Organized Crime).

${ }^{2}$ Konvensi ini adalah UNCAC (United Nations Convention Against Corruption).
} 
model atau acuan bagi pembuatan aturan hukum tentang ekstradisi nasional suatu negara.

Dalam keadaan Indonesia yang sekarang ini penuh dengan polemik khususnya dalam kondisi politik, sosial dan penegakan hukum Indonesia, masalah mengenai ekstradisi dianggap semakin penting. Hal ini dikarenakan beberapa tahun belakangan ini, Indonesia sangat aktif dalam memburu para pelaku kejahatan yang melarikan diri ke luar negeri. Untuk membawa kembali para pelaku tersebut, kerjasama internasional dengan negara-negara yang selama ini menjadi tempat pelarian para pelaku kejahatan di Indonesia terus diupayakan, salah satunya adalah dengan mendorong dibuatnya perjanjian ekstradisi. Indonesia hingga sejauh ini telah membuat 8 (delapan) perjanjian ekstradisi dengan beberapa negara. Adapun beberapa negara yang sudah terikat perjanjian Ekstradisi dengan Indonesia yaitu Malaysia, Philipina, Thailand, Australia, Papua Nugini, Hong Kong, Korea Selatan dan Singapura. Hingga saat ini, Indonesia sedang mengupayakan banyak perjanjian ekstradisi dengan negara- negara yang dijadikan tempat pelarian bagi para pelaku kejahatan.

Informasi teranyar perihal ekstradisi di Indonesia yang didapatkan, bahwa pada tanggal 14 Februari 2018 di Singapura, negara-negara ASEAN (Negara-negara di kawasan Asia Tenggara) telah menyepakati Model Perjanjian Ekstradisi. ${ }^{3}$ Dengan diratifikasinya berbagai perjanjian internasional di bidang kerjasama pidana, khususnya ekstradisi, baik perjanjian yang bersifat bilateral maupun multilateral, Indonesia dibebani kewajiban untuk mengimplementasikan perjanjian-perjanjian internasional tersebut, baik dalam tataran pelaksanaan konkrit di lapangan maupun dalam tataran legislasi (peraturan perundangan undangan).

Untuk mewujudkan hal itu, dibutuhkan politik hukum demi terciptanya suatu kepastian dalam penegakan hukum di Indonesia. Dalam tataran legislasi, Indonesia perlu melakukan penyesuaian atau harmonisasi terhadap peraturan perundang-undangan yang mengatur

\footnotetext{
${ }^{3} \mathrm{https}: / / \mathrm{www} . \mathrm{cnnindonesia.com/internasional/20}$ 180214182201-106-276241/negara-aseansepakati-model-perjanjian-ekstradisi.
} 
ekstradisi agar sesuai atau selaras dengan ketentuan-ketentuan atau norma-norma yang ada dalam perjanjian internasional. Landasan hukum bagi pembentukan perjanjian-perjanjian di bidang ekstradisi antara Indonesia dengan negara-negara lain adalah Undang-Undang Nomor 1 Tahun 1979 tentang Ekstradisi (selanjutnya disebut UU No. 1 Tahun 1979). Undangundang ini dijadikan dasar ketika Indonesia bernegosiasi dengan negara lain dan juga menjadi rujukan bagi DPR untuk menyetujui dokumen ratifikasi. Selain itu, Undang-undang ini menjadi pedoman untuk mengirim atau meminta pelaku kejahatan untuk diekstradisi. Namun seiring dengan meningkatnya kebutuhan terhadap perjanjianperjanjian ekstradisi antara Indonesia dengan negara lain dan bertambahnya jumlah permintaan ekstradisi dari dan ke luar negeri, undang-undang ekstradisi yang berlaku sekarang ini dirasakan belum mampu memberikan pedoman yang memadai bagi pelaksana di lapangan.

Beberapa permasalahan yang menonjol dalam praktek pelaksananaan undang-undang Ektradisi tersebut di antaranya adalah alasan penolakan atas suatu permintaan ekstradisi, prosedur yang tidak efisien dan lemahnya koordinasi antar lembaga atau instansi yang terlibat dalam pelaksanaan ekstradisi ini, terutama sehubungan dengan adanya permintaan ekstradisi dari luar negeri.

Disamping karena keperluan untuk menyesuaikan dengan perkembangan hukum internasional di bidang ekstradisi, perubahan UU No. 1 Tahun 1979 diharapkan juga dapat melakukan penyesuaian atau harmonisasi dengan peraturan perundang-undangan nasional lainnya, mengingat ekstradisi merupakan bagian dari hukum pidana, maka UU No. 1 Tahun 1979 perlu diselaraskan dengan ketentuanketentuan atau norma-norma yang diatur dalam peraturan perundangundangan pidana nasional lainnya.

\section{PERMASALAHAN}

Berdasarkan latar belakang yang telah dipaparkan sebelumnya, maka hal yang dijadikan permasalahan adalah:

1. Bagaimana ketentuan hukum ekstradisi di Indonesia dan perkembangannya?

2. Bagaimana upaya penyesuaian ketentuan hukum ekstradisi di 
Indonesia dengan perkembangan

ekstradisi secara internasional?

\section{METODE PENELITIAN}

Metode penelitian dalam penulisan ini merupakan metode penelitian yang bersifat kualitatif, dimana pendekatan yang digunakan adalah yuridis normatif. Maksud dari penggunaan pendekatan ini adalah dengan mencari permasalahan yang diangkat dari literatur-literatur atau bahan bacaan yang bersumber dari studi kepustakaan. Selanjutnya mengenai spesifikasi penelitian yang terkandung di dalam tulisan ini adalah deskriptif analitis, yakni dengan memberikan gambaran terhadap masalah yang diangkat dengan memberikan analisis dari pemecahan masalah sehingga mampu memberikan jawaban atas permasalahan tersebut berupa penjelasan-penjelasan yang konkrit.

Metode pengumpulan data dalam penelitian ini adalah menggunakan studi kepustakaan (library research) yang mana mengumpulkan bahan-bahan berupa dokumen berasal dari peraturan perundang-undangan atau sejenisnya dan bahan pustaka yang digunakan dalam penelitian ini berupa sumber- sumber bacaan dari tulisan para ahli di bidang hukum. Selanjutnya data dianalisis secara kualitatif normatif, yaitu melakukan penelitian dengan jalan menafsirkan dan membangun pernyataan yang terdapat dalam dokumen peraturan perundangundangan.

\section{PEMBAHASAN}

\section{A. Ekstradisi dan Perkembangannya di Indonesia}

Pengertian Ekstradisi menurut UU No. 1 tahun 1979 ada di dalam rumusan Pasal 1 yang menyebutkan, Ekstradisi adalah penyerahan oleh suatu negara yang meminta penyerahan seseorang yang disangka atau dipidana karena melakukan suatu kejahatan di luar wilayah negara yang menyerahkan dan di dalam yurisdiksi wilayah negara yang meminta penyerahan tersebut, karena berwenang untuk mengadili dan memidananya. Ekstradisi dilakukan atas dasar suatu perjanjian (treaty) antara negara yang meminta dengan negara yang diminta, jika belum ada perjanjian maka ekstradisi dapat dilakukan atas dasar hubungan baik dan jika kepentingan negara (dalam hal ini 
POLITIK HUKUM DALAM PEMBAHARUAN PERATURAN EKSTRADISI DI INDONESIA DIHUBUNGKAN DENGAN UN MODEL TREATY ON EXTRADITION OF 1990 : Zarisnov Arafat dan Muhammad Gary Gagarin Akbar

Negara Republik Indonesia) menghendakinya (Pasal 2 ayat 1 dan 2).

Dari uraian tersebut, tampak jelas tentang apa yang dinamakan ekstradisi. Ditinjau dari asal katanya, ekstradisi berasal dari bahasa Latin "Extradere". Ex berarti keluar, sedangkan Tradere berarti memberikan atau menyerahkan, dalam kata bendanya dapat dikatakan "Extraditio" yang berarti penyerahan. Tegasnya, yang dimaksud ekstradisi adalah penyerahan yang dilakukan secara formal baik berdasarkan perjanjian ekstradisi yang diadakan sebelumnya atau berdasarkan prinsip timbal balik (resiprositas) atas seorang yang dituduh melakukan tindak pidana (tersangka atau terdakwa) atau atas seseorang yang telah dijatuhi hukuman atas kejahatan yang dilakukan (terpidana) oleh negara tempatnya melarikan diri atau berada atau bersembunyi kepada negara yang memiliki yurisdiksi, untuk mengadili atau menghukumnya atas permintaan dari negara tersebut dengan tujuan untuk mengadili. ${ }^{4}$

Istilah ekstradisi menunjukkan proses dimana berdasarkan suatu asas

\footnotetext{
${ }^{4}$ C.Oppenheim, International Law 8th edition, (E-book) terjemahan, 2000, hlm. 696.
}

timbal balik atau berdasarkan perjanjian antar negara, suatu negara menyerahkan kepada negara yang lain, atas permintaannya, seorang pelaku kejahatan atau tersangka, karena negara yang meminta berwenang untuk mengadili pelaku atau tersangka tersebut. ${ }^{5}$ Huala Adolf menyebutkan:

"Ekstradisi adalah proses penyerahan seorang atau terpidana karena telah melakukan suatu kejahatan yang dilakukan secara formal oleh suatu negara kepada negara lain yang berwenang memeriksa dan mengadili penjahat tersebut. Jelasnya penyerahan tersebut dilakukan oleh negara tempat orang itu berlindung kepada negara yang meminta penyerahan". 6

Maksud dan tujuan ekstradisi adalah untuk menjamin agar pelaku kejahatan berat tidak dapat menghindarkan diri dari penuntutan atau pemidanaan, karena seringkali suatu negara yang wilayahnya dijadikan tempat berlindung oleh seseorang penjahat tidak dapat menuntut atau menjatuhkan pidana kepadanya. Hal ini semata-mata disebabkan oleh beberapa aturan tekhnis hukum pidana atau karena tidak adanya

\footnotetext{
${ }^{5}$ FX Adji Samekto dan Doddy Kridasaksana, Negara Dalam Tata Tertib Hukum Internasional, Buku Ajar Mata Kuliah Hukum Internasional Lanjut, UNDIP, 2004, hlm. 69.

6 Huala Adolf, Aspek Negara dalam Hukum Internasional, Grafindo, Bandung, 1990, hlm. 35 .
} 
POLITIK HUKUM DALAM PEMBAHARUAN PERATURAN EKSTRADISI DI INDONESIA DIHUBUNGKAN DENGAN UN MODEL TREATY ON EXTRADITION OF 1990 : Zarisnov Arafat dan Muhammad Gary Gagarin Akbar

yurisdiksi atas penjahat tersebut, karena itulah patut dan tepat penjahat tersebut diserahkan untuk diperiksa dan diadili oleh negara yang memiliki yurisdiksi atas penjahat tersebut. ${ }^{7}$

Dalam pengajuan permohonan ekstradisi, ada beberapa asas yang harus diperhatikan, diantaranya:

1. Asas Kejahatan Ganda (Double Criminality).

Menurut asas ini, kejahatan yang dijadikan sebagai alasan untuk meminta ekstradisi atas orang yang diminta, haruslah merupakan kejahatan (tindak pidana) baik menurut hukum negara peminta maupun hukum negara diminta. Dalam hal ini tidaklah perlu nama ataupun unsur-unsurnya semuanya harus sama, mengingat sistem hukum masing-masing negara itu berbeda-beda. Sudah cukup jika hukum kedua negara sama-sama mengklasifikasikan kejahatan itu sebagai kejahatan atau tindak pidana.

7 M. Budhiarto, Masalah Ekstradisi dan Jaminan Perlindungan atas Hak Asasi Manusia, Ghalia Indonesia, Jakarta, 1980, hlm. 14.
2. Asas Kekhususan atau Spesialitas.

Apabila orang yang diminta telah diserahkan, negara peminta hanya boleh mengadili dan atau menghukum orang yang diminta, hanyalah berdasarkan pada kejahatan yang dijadikan alasan untuk meminta ekstradisinya. Jadi dia tidak boleh diadili dan atau dihukum atas kejahatan lain, selain daripada kejahatan yang dijadikan sebagai alasan untuk meminta ekstradisi.

3. Asas tidak menyerahkan pelaku kejahatan politik.

Jika negara diminta berpendapat, bahwa kejahatan yang dijadikan sebagai alasan untuk meminta ekstradisi oleh negara peminta adalah tergolong sebagai kejahatan politik, maka negara diminta harus menolak permintaan tersebut. Tentang apa yang disebut dengan kejahatan politik, serta apa kriterianya, hingga kini tidak ada kesatuan pendapat, baik di kalangan para ahli maupun dalam praktek negara-negara, 
apakah suatu kejahatan

digolongkan sebagai kejahatan politik ataukah tidak? memang masalah politik merupakan masalah yang didasarkan pada pertimbangan-pertimbangan

politik yang tentu saja sangat subjektif. Oleh karena sukarnya menentukan kriteria objektif tentang kejahatan politik tersebut, maka dalam perkembangan dari lembaga ekstradisi ini, negara-negara baik dalam perjanjian maupun dalam peraturan perundang-undangan ekstradisinya, menggunakan sistem negatif, yaitu dengan menyatakan secara tegas bahwa kejahatan-kejahatan tertentu secara tegas dinyatakan sebagai bukan kejahatan politik, atau dinyatakan sebagai kejahatan yang dapat dijadikan alasan untuk meminta maupun mengekstradisikan orang yang diminta (extraditable crime).

4. Asas tidak menyerahkan warga negara.

J.G.Starke mengatakan bahwa Kewarganegaraan itu tiada lain daripada keanggotaan seseorang pada suatu negara. Sebagai anggota dari suatu negara sudah tentu hubungannya dengan negara dimana dia menjadi anggota atau kewarganegaraan, mengandung segi kekhususan tersendiri pula. $^{8}$ Jika orang diminta ternyata adalah warga negara dari negara diminta, maka negara diminta dapat menolak permintaan dari negara peminta. Asas ini berlandaskan pada pemikiran, bahwa negara berkewajiban melindungi warga negaranya dan sebaliknya warga negara memang berhak untuk memperoleh perlindungan dari negaranya, tetapi jika negara diminta menolak permintaan negara peminta, negara diminta tersebut berkewajiban untuk mengadili dan atau menghukum warga negaranya itu berdasarkan pada hukum nasionalnya sendiri.

\footnotetext{
${ }^{8}$ Artikel Akrial Zul, Asas Tidak Menyerahkan Warga Negara Sendiri Dikaitkan Dengan Politik Hukum Nasional, diakses dari situs www. Legalitas.org.
} 
5. Asas Kewilayahan

Asas bahwa suatu kejahatan

yang telah dilakukan seluruhnya atau sebagian di wilayah yang termasuk atau tidak dianggap termasuk dalam jurisdiksi Negara yang diminta, maka Negara itu dapat menolak permintaan ekstradisi.

\section{Asas Resiprositas}

Di Indonesia sendiri, walaupun telah diatur di dalam Pasal 2 ayat 1 UU No. 1 tahun 1979 yang menegaskan kesediaan Indonesia untuk melakukan ekstradisi atau penyerahan atas diri seseorang pelaku kejahatan, apabila antara Indonesia dengan negara yang meminta tersebut sudah terikat dalam suatu perjanjian ekstradisi, namun selain atas dasar suatu perjanjian, Indonesia juga menyatakan kesediaan untuk melakukan ekstradisi atas dasar hubungan baik dengan pihak atau negara lain (Pasal 2 ayat 2 UU No. 1 tahun 1979).
7. Asas Non Bis In Idem atau Ne Bis In Idem

Mengenai asas ini, Indonesia telah memuatnya di dalam peraturan perundang-undangan, yaitu dalam Pasal 76 ayat 1 KUHP (Kitab Undang-undang Hukum Pidana):

"Kecuali dalam hal putusan hakim masih mungkin diulangi, orang tidak boleh dituntut dua kali karena perbuatan yang oleh hakim indonesia terhadap dirinya telah diadili dengan putusan yang menjadi tetap (in kracht van gewijsde)".

Ketentuan Pasal 76 ayat 1 diletakan menjadi dasar asas ne bis in idem yang melarang negara untuk menuntut yang kedua kalinya terhadap si pembuat yang perbuatannya telah diputus oleh pengadilan yang putusan mana telah mempunyai kekuatan hukum tetap. Putusan hakim yang telah mempunyai kekuatan hukum tetap ialah putusan yang tidak dapat lagi dilawan dengan upaya hukum biasa. ${ }^{9}$ Dalam UU No. 1

\footnotetext{
9 Adami Chazawi, Pelajaran Hukum Pidana Bagian II (buku 2), Raja Grafindo Persada, Jakarta, 2002, hlm. 152.
} 
Tahun 1979 Tentang Ekstradisi, asas ne bis in idem terdapat dalam Pasal 10 yang berbunyi:

"Permintaaan ekstradisi ditolak, jika putusan yang dijatuhkan oleh Pengadilan Republik Indonesia yang berwenang mengenai kejahatan yang dimintakan ekstradisinya telah mempunyai kekuatan hukum yang pasti”.

Asas ini selain sebagai salah satu asas Hukum pidana (nasional dan internasional) juga merupakan asas ekstradisi. Adapun tujuan dari asas ini adalah untuk memberikan kepastian hukum bagi setiap orang pada umumnya. Orang yang sudah dijatuhi putusan pidana dengan kekuatan mengikat dan tetap, tidak dapat diadili atau dijatuhi hukuman untuk kedua kali atau lebih atas kasus kejahatan sama. ${ }^{10}$

\section{Asas Daluwarsa}

Daluwarsa atau lewat waktu dikenal dalam hampir semua sistem hukum negara-negara di dunia. Makna dari daluwarsa ini

${ }^{10}$ I wayan Parthiana, Ekstradisi dalam Hukum Internasional dan Hukum Nasional Indonesia (buku 2), Alumni, Bandung,1983, hlm.172. adalah memberikan adanya suatu kepastian hukum bagi semua pihak, bahwa suatu peristiwa hukum apabila sudah sedemikian lama terjadinya, misalnya sudah terjadi sekian tahun yang lampau dan selama ini tetap dibiarkan saja dalam semua pihak, sehingga sudah dilupakan, seolah-olah tidak pernah terjadi maka setelah sampai atau melewati jangka waktu tertentu tidak dapat dilakukan upaya hukum apapun. Mengenai berapa lama suatu peristiwa hukum sudah dianggap daluwarsa, hal ini berbeda-beda dalam setiap sistem hukum negara. Permintaan negara peminta harus ditolak apabila penuntutan atau pelaksanaan hukuman terhadap kejahatan yang dijadikan sebagai alasan untuk meminta ekstradisi atas orang yang diminta, sudah daluwarsa menurut hukum dari satu atau kedua pihak.

Adapun ekstradisi hingga saat ini mengalami perubahan semakin baik, terutama setelah kehidupan bernegara 
sudah mulai tampak agak lebih maju, khususnya mulai abad ke-17, apalagi setelah Perjanjian Perdamaian Westphalia tahun 1648, dengan lahirnya negara-negara yang berdasarkan prinsip kewilayahan kebangsaan kemerdekaan, kedaulatan, dan kesamaan derajat, yang kemudian terus bertambah kokoh memasuki abad 18, 19, sampai awal abad 20 hingga perang dunia ke-2 (1939-1945). Hubungan dan pergaulan internasional pun menemukan bentuk dan substansinya yang baru dan berbeda dengan jaman sebelum Perjanjian Perdamaian Westphalia tahun $1648 .{ }^{11}$ Negara-negara yang berdasarkan atas prinsip kemerdekaan kedaulatan dan kedudukan sederajat mulai menata dirinya masing-masing terutama masalah domestik dengan membentuk dan mengembangkan hukum nasionalnya, yang salah satunya di bidang hukum pidana nasional. Hukum pidana nasional masing-masing negara, terutama jenis-jenis kejahatan atau tindak pidananya, disamping pula ada kesamaan dan perbedaannya.

Semakin menguat batas wilayah dan kedaulatan teritorial masing-masing

\footnotetext{
${ }^{11}$ I Wayan Parthiana, Ekstradisi dalam Hukum Internasional Modern,Cetakan I, Yrama Widya,Bandung, 2009, hlm. 27.
}

negara, semakin menguat pula penerapan hukum nasionalnya di dalam batas wilayah negara masing-masing. Demikian pula dengan identitas kebangsaan atau kewarganegaraan dari tiap orang semakin jelas, sehingga menjadi lebih mudah bagi suatu negara untuk membedakan antara orang yang tergolong sebagai warganegaranya dan yang bukan warganegaranya atau orang asing. Berkenaan dengan pelaku kejahatan juga akan lebih mudah dapat dikenali kewarganegarannya. Pada pihak lain, hubungan-hubungan internasional pun mengalami perkembangan yang cukup pesat. Hal ini antara lain ditandai oleh semakin banyaknya perjanjian-perjanjian yang dibuat oleh negara-negara baik bilateral ataupun multilateral untuk mengatur suatu masalah tertentu yang sudah, sedang, dan akan dihadapi. Dalam pembuatan perjanjian tersebut mulai dilakukan pengkhususan atas substansinya, jadi tidak lagi satu perjanjian mencakup berbagai macam substansi yang berbeda-beda.

\section{B. Upaya Penyesuaian Ketentuan \\ Hukum Ekstradisi di Indonesia dengan UN Model Treaty on Extradition}


Membahas mengenai penyesuaian ketentuan hukum di Indonesia dengan aturan-aturan hukum yang berlaku secara internasional maka tidak terlepas dari kajian politik hukum. Menurut pendapat Teuku Mohammad Radhie (dalam bukunya Imam Syaukani dan A. Ahsin Thohari):

"Politik Hukum adalah sebagai suatu pernyataan kehendak penguasa negara mengenai hukum yang berlaku di wilayahnya dan mengenai arah perkembangan hukum yang dibangun. "12

Dari pendapat tersebut, penulis berpendapat bahwa penguasa negara dalam hal ini Presiden Republik Indonesia harus dapat mengarahkan perkembangan hukum ke arah yang lebih konkrit lagi demi tercapainya penegakan hukum yang berlandaskan kepastian hukum mengenai ekstradisi terhadap seseorang yang diduga melakukan suatu kejahatan atau tindak pidana. Perkembangan Ekstradisi pada abad 20 dan abad 21 telah mengalami perubahan besar dibandingkan dengan sejak awal perkembangannya. Perkembangan awal ekstradisi sesuai

12 Imam Syaukani dan A. Ahsin Thohari, Dasar-dasar Politik Hukum, RajaGrafindo Persada, Jakarta, 2013, hlm 27. dengan prinsip hukum internasional dimana individu dipandang bukan subjek hukum internasional, kecuali Negara. Dengan semakin pesat perkembangan hak asasi manusia, individu tidak lagi dijadikan objek ekstradisi melainkan telah ditempatkan sebagai subjek dalam setiap perjanjian ekstradisi dan pelaksanaan perjanjian Ekstradisi. Perkembangan ekstradisi tersebut diperkuat dengan keberadaan UN Model Treaty on Extradition of 1990 yang dikembangkan oleh Perserikatan Bangsa-Bangsa.

Prinsip ekstradisi yang disetujui secara universal seperti tercantum dalam UN Model Treaty on Extradition tersebut, yaitu mengenai prinsip tidak menyerahkan pelaku kejahatan politik dan penolakan atas dasar adanya proses penuntutan atau peradilan yang tidak jujur atau penghukuman yang tidak dikehendaki (seperti hukuman mati). Adapun beberapa asas yang dianut di dalam UN Model Treaty on Extradition of 1990, adalah:

1. Double Criminality (tidak terbatas pada kesamaan kategori atau terminologi saja, tapi dilihat juga elemen-elemen tindak 
pidana dan fakta-fakta

kejahatan);

2. Kejahatan politik tidak dapat diekstradisikan (mandatory);

3. Tidak mengekstradisi warga negaranya (optional);

4.

Simplified Extradition

Procedures

(prosedur

ekstradisi dapat disimpangi sepanjang ada persetujuan dari orang yang dimintakan ekstradisi);

5. Rule of Speciality/Asas Spesialitas.

\section{UN Model Treaty on Extradition} memuat 18 pasal, dan yang sangat mencolok adalah secara rinci diatur perihal penolakan permohonan ekstradisi, baik yang bersifat wajib (mandatory) maupun bersifat pilihan (optional), sebagaimana dicantumkan dalam Pasal 3 yang mengatur mengenai penolakan yang bersifat wajib (Mandatory Grounds for Refusal), dan Pasal 4 yang mengatur mengenai penolakan yang bersifat pilihan (Optional Ground for Refusal).
Ekstradisi wajib (mandatory) ditolak karena hal-hal sebagai berikut ${ }^{13}$ :

1. Kejahatan yang dimintakan untuk diekstradisi adalah kejahan yang bersifat politik;

2. Ada kemungkinan bahwa permintaan ekstradisi yang diminta dengan maksud untuk menuntut atau menghukum berdasarkan alasan ras, agama, kebangsaan, asal usul etnik, pandangan politik, jenis kelamin atau status;

3. Kejahatan yang dimintakan ekstradisi adalah kejahatan militer;

4. Orang dimintakan ekstradisi telah di jatuhi hukuman yang telah mempunyai kekuatan hukum tetap;

5. Orang yang dimintakan ekstradisi adalah orang yang kebal terhadap tuntutan hukum;

6. Jika orang yang kejahatannya dimintakan ekstradisi akan dikenakan penyiksaan, perlakuan yang kejam dan di luar batas perikemanusiaan atau terhadap orang yang

${ }^{13}$ Article 3 UN Model Treaty on Extradition of 1990 
bersangkutan tidak ada jaminan

minimum dari Negara yang

Meminta Ekstradisi (Negara

Peminta) akan diperlakukan

sesuai dengan standar Kovenan

Internasional mengenai Hak

Sipil dan Hak Politik;

7. Jika Putusan Pengadilan Negara

Peminta telah dijatuhkan secara

in absensia untuk kejahatan yang

dimintakan ekstradisi;

Sementara itu, penolakan ekstradisi yang bersifat pilihan (optional) meliputi: ${ }^{14}$

1. Ekstradisi terhadap warga negara dari negara yang diminta;

2. Jika pejabat yg berwenang di Negara diminta tidak ada niat untuk melakukan atau menghentikan penuntutan terhadap seseorang yang dimintakan ekstradisi;

3. Jika penuntutan atas seseorang yang dimintakan ekstradisi ditunda di negara yang diminta;

4. Jika kejahatan atas mana seseorang dimintakan ekstradisi

${ }^{14}$ Article 4 UN Model Treaty on Extradition of 1990 diancam dengan pidana mati di negara yang meminta ekstradisi kecuali negara peminta memberikan jaminan bahwa, terhadap orang yang dimintakan ekstradisi itu tidak akan dijatuhi pidana mati sekalipun UndangUndang (selanjutnya disebut UU) yang berlaku mengatur tentang pidana mati;

5. Jika kejahatan tersebut dilakukan di luar wilayah jurisdiksi negara yang meminta dan negara yang diminta dan negara yang diminta tidak memiliki jurisdiksi atas kejahatan tersebut;

6. Jika Kejahatan untuk mana seseorang dimintakan ekstradisi telah dilakukan seluruhnya atau sebagian di negara diminta. Jika permintaan ekstradisi ditolak atas alasan ini maka pihak berwenang di negara yang diminta wajib melaksanakan penuntutan terhadap orang dimaksud;

7. Jika seseorang untuk kejahatan mana dimintakan ekstradisi telah dijatuhi hukuman atau akan diadili dan dihukum di negara 
yang meminta oleh pengadilan Ad hoc atau pengadilan khusus;

8. Jika Negara yang diminta, mempertimbangkan bahwa, ekstradisi terhadap orang yang bersangkutan akan bertentangan dengan pertimbangan kemanusiaan baik dari sisi usia, kesehatan atau keadaan pribadi yang bersangkutan.

Tidak ada satu pun ketentuan dalam UN Model Treaty yang mengatur mengenai kewajiban untuk menerima permohonan ekstradisi. Terkesan bahwa PBB lebih mendahulukan mengenai prosedur daripada efektivitas pencegahan dan pemberantasan kejahatan transnasional, sedangkan tujuan utama dari konvensi-konvensi PBB mengenai kejahatan transnasional (Konvensi Palermo tahun 2000/UNTOC) adalah meningkatkan kerjasama antar negara-negara anggota PBB untuk mencegah dan memberantas kejahatan transnasional yang terorganisasi. Implikasi dari perkembangan ekstradisi terkait perkembangan Hak Asasi Manusia, telah mengubah konsep ekstradisi semula yang hanya didasarkan pada meningkatkan efektivitas hubungan antara negara peminta (requesting State) dan negara yang diminta (requested State) untuk tujuan pencegahan dan pemberantasan kejahatan, berubah tidak lagi bertumpu pada masalah tersebut melainkan lebih mengutamakan pada bagaimana cara yang benar dan tidak mengurangi efektivitas proses hubungan antar negara dalam pencegahan dan pemberantasan kejahatan transnasional.

Dalam hal penolakan terhadap permintaan ekstradisi, Undang-undang nasional Indonesia juga mengaturnya, walaupun tidak secara rinci dibedakan alasan penolakan tersebut berupa kewajiban atau pilihan untuk menolak ekstradisi. Adapun alasan penolakan tersebut dimuat di dalam beberapa pasal pada UU No. 1 Tahun 1979 tentang ekstradisi, dengan beberapa ketentuan yaitu:

1. Ekstradisi tidak dilakukan terhadap kejahatan politik (Pasal 5 ayat 1-4);

2. Ekstradisi tidak dilakukan terhadap kejahatan menurut hukum pidana militer, kecuali dalam perjanjian diatur lain (Pasal 6); 
3. Ekstradisi ditolak terhadap warga negara Republik Indonesia (Pasal 7 ayat 1-2);

4. Permintaan ekstradisi dapat ditolak jika kejahatan dilakukan seluruhnya atau sebagiannya dalam wilayah Negara Republik Indonesia (Pasal 8);

5. Permintaan ekstradisi dapat ditolak jika orang yang diminta sedang diproses di Negara Republik Indonesia untuk kejahatan yang sama (Pasal 9);

6. Permintaan ekstradisi ditolak, jika putusan yang dijatuhkan oleh Pengadilan Republik Indonesia mengenai kejahatan yang dimintakan ekstradisinya telah mempunyai kekuatan hukum yang pasti (Pasal 10);

7. Permintaan ekstradisi ditolak, apabila orang yang dimintakan ekstradisinya telah diadili dan dibebaskan atau telah selesai menjalani pidananya di negara lain mengenai kejahatan yang dimintakan ekstradisinya (Pasal 11);

8. Permintaan ekstradisi ditolak, jika menurut hukum Negara Republik Indonesia hak untuk menuntut atau hak untuk melaksanakan putusan pidana telah kedaluwarsa (Pasal 12);

9. Permintaan ekstradisi ditolak, jika kejahatan yang dimintakan ekstradisi, diancam dengan pidana mati menurut hukum negara peminta, kecuali jika negara peminta memberikan jaminan bahwa pidana mati tidak akan dilaksanakan (Pasal 13);

10. Permintaan ekstradisi ditolak, jika orang yang dimintakan ekstradisinya akan dituntut, dipidana, atau dikenakan tindakan lain karena alasan yang bertalian dengan agamanya, keyakinan politiknya, atau kewarganegaraannya, ataupun karena ia termasuk suku bangsa atau golongan penduduk tertentu (Pasal 14);

11. Permintaan ekstradisi ditolak, jika orang yang dimintakan ekstradisi akan dituntut, dipidana, atau ditahan karena melakukan kejahatan lain daripada kejahatan yang karenanya ia dimintakan ekstradisinya, kecuali dengan izin Presiden (Pasal 15); dan 
12. Permintaan ekstradisi ditolak, jika orang yang dimintakan ekstradisinya akan diserahkan kepada negara ketiga untuk kejahatan-kejahatan lain yang dilakukan sebelum ia dimintakan ekstradisi itu (Pasal 16).

Jika dibandingkan, substansi Undangundang No. 1 tahun 1979 tidak terlalu lengkap memuat aturan tentang penolakan ekstradisi, seperti alasan wajib penolakan ekstradisi yang dimuat dalam UN Model Treaty on Extradition pada article 3 point $f$ yang menyebutkan:

"If the person whose extradition is requested has been or would be subjected in the requesting State to torture or cruel, inhuman or degrading treatment or punishment or if that person has not received or would not receive the minimum guarantees in criminal proceedings, as contained in the International Covenant on Civil and Political Rights" (Jika orang yang kejahatannya dimintakan ekstradisi akan dikenakan penyiksaan, perlakuan yang kejam dan di luar batas perikemanusiaan atau terhadap orang yang bersangkutan tidak ada jaminan minimum dari Negara yang Meminta Ekstradisi (Negara Peminta) akan diperlakukan sesuai dengan standar Kovenan Internasional mengenai Hak Sipil dan Hak Politik).
Dari alasan tersebut, dikhawatirkan apabila permintaan ekstradisi yang dikabulkan akan munculnya suatu bentuk tindakan pelanggaran hak asasi manusia terhadap orang yang dimintakan ekstradisi terhadapnya, sehingga materi muatan dalam Undangundang Nomor 1 tahun 1979 harus mengatur hal tersebut. Alasan mendasar untuk dapat segera dilakukannya perubahan dan/atau penambahan substansi mengenai hal tersebut adalah demi terwujudnya perlindungan terhadap hak-hak mendasar yang melekat pada manusia dan mewujudkan cita hukum berupa kepastian hukum, keadilan dan kemanfaatan, mengingat kajian keilmuan hukum itu harus selalu berkembang menyesuaikan dengan peradaban manusia ke arah yang lebih baik dan harus mengedepankan sifat yang manusiawi.

\section{KESIMPULAN}

Berdasarkan analisis dan kajian terhadap permasalahan yang telah dibahas maka penulis dapat memberikan kesimpulan sebagai berikut:

1. Perkembangan kajian ekstradisi di Indonesia seharusnya sudah 


$$
\begin{array}{lr}
\begin{array}{l}
\text { menjadi fokus pemerintah } \\
\text { Indonesia yang }
\end{array} & \text { harus } \\
\text { diprioritaskan, } & \text { mengingat } \\
\text { peraturan yang menjadi landasan } \\
\text { hukumnya dibuat pada tahun } \\
1979 \text { sedangkan memperhatikan } \\
\text { periode dari masa tersebut } \\
\text { hingga saat ini harus adanya } \\
\text { suatu perubahan r yang } \\
\text { disesuaikan } \\
\text { perkembangan zaman dan } \\
\text { kebutuhan } \\
\text { internasional. }
\end{array}
$$

2. Substansi dalam Undang-undang Nomor 1 tahun 1979 tentang penolakan ekstradisi dianggap tidak terlalu lengkap dan belum mengikuti perkembangan hukum internasional mengenai ekstradisi, sehingga harus ada tambahan di dalam materi muatan Undang-undang Nomor 1 tahun 1979 menyesuaikan dengan isi dari UN Model Treaty on Extradition of 1990 demi terwujudnya pembaharuan hukum kedepannya yang lebih baik.

\section{DAFTAR PUSTAKA}

\section{A. Buku}

Adami Chazawi, Pelajaran Hukum Pidana Bagian II (buku 2), Raja Grafindo Persada, Jakarta, 2002.

C. Oppenheim, International Law 8th edition, (E-book) terjemahan, 2000.

FX Adji Samekto dan Doddy Kridasaksana, Negara Dalam Tata Tertib Hukum Internasional, UNDIP, 2004.

Huala Adolf, Aspek Negara dalam Hukum Internasional, Grafindo, Bandung, 1990.

I Wayan Parthiana, Ekstradisi dalam Hukum Internasional dan Hukum Nasional Indonesia (buku 2), Alumni, Bandung, 1983.

\section{Ekstradisi}

dalam Hukum Internasional Modern, Cetakan I, Yrama Widya, Bandung, 2009.

Imam Syaukani dan A. Ahsin Thohari, Dasar-dasar Politik Hukum, 
RajaGrafindo Persada,

Jakarta, 2013.

M. Budhiarto, Masalah Ekstradisi dan Jaminan Perlindungan atas Hak Asasi Manusia, Ghalia Indonesia, Jakarta, 1980.

\section{B. Peraturan Perundang-undangan}

Undang-Undang Nomor 1 Tahun 1979 Tentang Ekstradisi

United Nations Convention Against Transnational Organized Crime of 2000 (UNTOC).

United Nations Convention Against Corruption of 2003 (UNCAC)

United Nations Model Treaty on Extradition of 1990

\section{Sumber Lainnya}

Artikel: Akrial Zul, Asas Tidak Menyerahkan Warga Negara Sendiri Dikaitkan Dengan Politik Hukum Nasional, diakses dari situs www. Legalitas.org.

https://www.cnnindonesia.com 